\title{
Wages, integration, migration motivation: cases of export industry employees in Tijuana and Tangiers-Tetouan
}

\author{
Kathryn Kopinak ${ }^{1 *}$, Jenna Hennebry², Rosa Maria Soriano-Miras ${ }^{3} \mathbb{D}$ and Antonio Trinidad Requena ${ }^{3}$
}

\author{
* Correspondence: kopinak@uwo.ca \\ ${ }^{1}$ King's University College at \\ Western University, 152 Albert St \\ \#24, London, ON N6A 1M1, Canada \\ Full list of author information is \\ available at the end of the article
}

\begin{abstract}
Recent commentaries on migration integration suggest that researchers focus more on cities than nation states and include considerations of political economy, societal inequality and shifts in production. This article analyses how different aspects of wages of export industry (EI) migrant and borderlander workers in Tijuana, Mexico and Tangiers-Tetouan, Morocco limit their socioeconomic integration and lead to their greater identification with foreign standards, stimulating emigration northward. Using the new theory of migration systems, real and indirect wages are found to be major system elements initiating and deepening inequality, and providing for comparisons between natives, foreigners and expatriates, creating relative deprivation. System dynamics, such as border characteristics, insecurity, and currency markets uniquely contribute to inadequate settlement south of the US border. While El wages are shown to poorly integrate migrant workers structurally in both cities, employment there supports incorporation into northern countries. The paper contributes to migration integration research by adding to the few studies which use wages as an indicator of integration and by focusing on low income regions instead of high income countries which constitute most previous research.
\end{abstract}

Keywords: Maquiladora, Export industry, Living wage, Migration system, Wage-labor, Integration

"Mexico wants to export goods, not people."

\section{Former President Salinas de Gortari}

Export processing is industrial production within developing countries, whereby foreign direct investors import supplies duty free with local government support. Taxes are paid only on value added, which is mainly labour (Kinoshita 2008). Northern Mexico and Morocco have attracted such investment because of their abundant, low cost labor at locations abutting large markets and their restructuring to facilitate it. Mexican export processors, called maquiladoras or maquilas, began in the mid-sixties

(c) The Author(s). 2020 Open Access This article is licensed under a Creative Commons Attribution 4.0 International License, which permits use, sharing, adaptation, distribution and reproduction in any medium or format, as long as you give appropriate credit to the original author(s) and the source, provide a link to the Creative Commons licence, and indicate if changes were made. The images or other third party material in this article are included in the article's Creative Commons licence, unless indicated otherwise in a credit line to the material. If material is not included in the article's Creative Commons licence and your intended use is not permitted by statutory regulation or exceeds the permitted use, you will need to obtain permission directly from the copyright holder. To view a copy of this licence, visit http://creativecommons.org/licenses/by/4.0/. 
and export production, as it is called in Morocco, arose in the 1980s. In Mexico in 2015, there were 5480 export industries [EIs] employing 2,315,788 people. The largest sectors were transport equipment (33\%), communication, computer and electrical equipment (18\%) metal products (8\%) and textile, clothing and leather goods (8\%). In 2012, there were 5190 EIs in Morocco. ${ }^{1}$ In 2009 , they employed 1,233,052 people, with these sectors retaining the most: clothing, textiles and furs (50\%), food (13\%), electrical, communication, radio and TV (13\%), chemical (5\%) and leather footwear (4\%). ${ }^{2}$

Both Mexico and Morocco are labor frontier countries that have undergone enough development permitting human mobility, but do not provide sufficient economic opportunity, resulting in internal and international migration (Stalker 2000). Before EIs' arrival, northern Mexico and Morocco were departure points for human migration from the global south northward. The large EI agglomerations there intersect historical migration routes and large portions of their labor forces are constituted by internal Mexican and Moroccan migrants (Acosta et al. 2015; Trinidad Requena et al. 2018). This paper uses a qualitative case study design to assess the integration of EI employees, mainly at the socioeconomic level, by considering their discourse on wages. Wages are key because study participants identified them as the greatest migration motivator. Interviewees viewed intervieewers incredulously when asked why those employed would emigrate and answered "pay" as if it was obvious.

Social scientists have overstressed how wage structures provide the cement for social order, building loyalty and maintaining morale (Rubery 1997). We attempt to add balance by studying EIs where companies relocated production to reduce costs, thereby being less likely to use wages for social cohesion. Without the anchoring role which wages play, labour migration is more likely.

As Saharso (2019) indicates, integration usually refers to socio-economic incorporation and also socio-cultural adaptation. This work focuses on how EI wages incorporate internal migrants socio-economically, but we also observe how EI employment may lead to cultural adaptation to the countries where capital originates. Saharso also refers to other definitions of integration which include a legal-political level. We ask how companies which give support for migration documents as a paid benefit contribute to legal integration abroad which may lead to emigration.

The cases studied are the western end of the US-Mexico border, called CaliBaja, and the place where Africa and Europe are closest, the Tangiers-Tetouan corridor and Spain (See Figures 1 and 2 in Additional file 1). The research sites are densely populated by EI employees who are potential emigrants. Tijuana has more maquilas than other Mexican locations, with 137,414 employees in $2009^{3}$ The Tangiers-Tetouan urban corridor had 67,891 employees in 2009. ${ }^{4}$ In Tijuana, 79\% of EI employees were workers (Hualde 2007, p. 239) and in Tangiers-Tetouan $94 \%{ }^{5}$ These labour forces have had regional impacts with Tangiers becoming Morocco's third largest city and Tijuana

\footnotetext{
${ }^{1}$ Office Des Changes. 2012. Exportations Du Maroc Ventilees Par Region. Royaume du Maroc. P. 8.

${ }^{2}$ Authors' calculations from data provided by the Direction des Statistiques et de la Veille. Ministère de l'Industrie, de Commerce et des Nouvelles Technologies. Royaume du Maroc. Décembre 2011.

${ }^{3}$ Authors' calculation from Inegi. Retreived from http://www.inegi.org.mx/sistemas/bie/?idserpadre $=1040011$ 0\#D10400110 May 18, 2016.

${ }^{4}$ Authors' calculations from data provided by the Direction des Statistiqueset de la Veille. Ministère de l'Industrie, de Commerce et des Nouvelles Technologies. Royaume du Maroc. Décembre 2011.

${ }^{5}$ Authors' calculations from data provided by the Direction des Statistiqueset de la Veille. Ministère de l'Industrie, de Commerce et des Nouvelles Technologies. Royaume du Maroc. Décembre 2011.
} 
Mexico's fifth largest. As Hadj Abdou (2019) and Favell (2019) argue, migration integration studies must look beyond the nation state and cities may be more appropriate foci.

Companies in these cases constitute wages differently. Comparing them allows the identification of which components of the pay packet may affect migration most and how. Using the new theory of migration systems (NTMS), the impacts of EI wages are separated from other factors affecting emigration. The paper addresses how the other factors enhance or dampen the impact of remuneration on migration.

The conceptualization of income put forward by Carr et al. (2016) was invoked by how participants talked about compensation. The authors distinguish between an econometric cut off point such as a minimum wage which enables people to function at a basic level and a living wage which goes further, permitting people to do what they value. Most researchers have calculated economic variables, such as basic living costs, to arrive at minimum wages, but they question whether such figures really deliver a good quality of living. They suggest also using a more theoretical and humanitarian way of understanding wages as giving people the capacity to transform their lives and improve their well-being, "calculated to enable meaningful participation in society through recreation, supporting a family, and saving for the future". (p. 3) The emphasis is on individuals and households, not businesses. Living wages vary across time and place. In addition to material support, living wages are estimated socially and are related to people's psychological sense of capability. Carr et al. (2016, p. 4) show how "perceived decent levels of income and fair processes of wage determination have .... been linked to motivation, performance and productivity at work". We show how such levels, or lack thereof, are related to emigration.

This conceptualization of income is very similar to the way it is treated in the EU context as a major indicator of social inclusion of groups in society. "Basic income and housing are prerequisites for structural integration in society" (Huddleston et al. 2013, p. 18). They are related to other areas of integration such as whether employment is a sufficient protection against poverty.

\section{Literature review}

Breidahl (2017) argues that the civic integration of immigrants is not limited to their citizenship, but also includes their labour market activation, which he observes has been treated very superficially in the civic literature. Few studies specifically use wages as an indicator of integration (Wanner 2019). One exception is Nekby (2002) who uses income as a dependent variable demonstrating Swedish integration.

Wages for all jobs have been linked to emigration at the two research sites. De Haas and Vezzoli (2014, p. 1405) suggest that higher income inequality in Mexico "might partly explain why emigration from Mexico has remained high despite comparatively high aggregate levels of economic development". Anderson (2012) relates emigration to per capital income gaps, which in 2009 were 3.4 for Mexico and the US and 6.6 for Spain and Morocco. Soriano-Miras (2018) found that for Mexican and Moroccan women, earning a wage decreased their integration into traditional gender norms and led to their anticipation of emigration.

The first research on EI wages and emigration focused on Asia. Export led growth in Korea and Taiwan stemmed migration by expanding wages and employment, but not 
in Thailand (Stalker 2000). Thai migration continued because export-led growth increased income gaps due to lack of extensive development of wage-labor (Charoenloet 2001, p. 176) Unlike slaves or peasants, wage-laborers are employed for a fixed price and time, have the status of permanent workers, and are entitled to social welfare, bonuses, promotions, and job security. Even during export growth, over half of the Thai labor force had jobs without wage-labor characteristics.

While there are vast literatures on maquiladora industrialization and Mexican emigration, very little links the two. Of the work making connections, early research found that maquiladora employment inhibited emigration (Bustamante 1983; Fernández-Kelly 1983; Seligson and Williams 1981), but later studies found a positive relationship (Carrillo 1990). A steady stream of migrants from Tijuana with maquila experience was detected (Fussell 2004).

An important reason to extend research on links between EI wages and migration is because wages have remained low for some time. Fussell (2000) found that Tijuana maquila workers earned less than those in other sectors of the local economy with similar education because the state, labor unions and managers' associations cooperated to maintain low wages. New findings on 16 large, innovative, upscaled maquilas in Mexico found that it was the exception for advanced techniques to be associated with social progress for employees, especially in regard to wages (Bensusán et al. 2017).

As a result of growth in Moroccan EIs from 1986 to 1995 which paid the lowest wages, real wages declined (Lane et al. 1999). A survey of Moroccan EIs from 1997 to 2000 found that wages had stagnated (Muller and Nordman 2008). Comparing Moroccan EIs with Mexican ones, Fafchamps (2009) found that although EIs had grown, higher wages were not paid to those with more education because most industries were labor intensive. In many Tangiers-Tetouan EIs, wages did not meet the requirements of the 2004 Labor Code stipulating that workers be paid at least the legal minimum (Trinidad Requena et al. 2018).

The continued low wage level is related to the opening of the Mexican and Moroccan economies and the adoption of export led development policies to attract foreign investment (Bensusán and Reygadas 2000). As a condition for World Bank credit, the Mexican government agreed to neoliberal reforms in 1984, which included several Economic Solidarity Pacts, the main priority of which was "the guarantee of cheap labor power to both domestic and foreign investors" (Dussel Peters 2004, p. 123). In response, maquilas grew. At a national level from 1988 to 1999, manufacturers with the highest productivity, which were also very active foreign traders, failed to match that productivity with adequate employment and real wages. Moroccan restructuring was promoted by the World Bank and the IMF in the 1990s, encouraging EIs. Unregulated labor standards, weak or non-existent unions and low wages are seen as ensuring competitiveness in a global market. Joining regional trade blocks, such as NAFTA and the Union for the Mediterranean, has consolidated these countries' role as low wage producers, since this is considered their comparative advantage.

\section{Theoretical framework}

Global markets overlay international migration systems, defined as places in different countries between which relatively large numbers of people move. Migration systems have been found in the regions containing the research sites, a Mexico-US system (Delgado 
Wise and Márquez Covarrubias 2008) and north African systems (De Haas 2008). Smaller migration systems exist within these. Chávez (2007, p. 197) found a "migrant labor system that incorporates Tijuana residents into the border regional labor market". People often use maquiladora employment to partly fulfil requirements for Border Crossing Cards (or laser visas). A Spanish-Moroccan migration system developed after Spain joined the EU, grew economically, creating the need for foreign labour, while Morocco's rural economy declined (White 2007). Spanish regions having become dependent on migrant labor are the agricultural south, Catalonia, the Basque Country and Madrid. With the opening of the Moroccan economy to foreign investment, this migration system has expanded to include transnational production bringing personnel south (Rios-Vargas 2015). As Favell (2019) argues, integration is not a property of an individual but of a social system. We ask how transnational production may affect the integration of EI employees in migration systems where the two cities are located.

The new theory of migration systems (NTMS) has incorporated more refined notions of agency, emergence and social mechanisms than previous versions. We follow Bakewell's (2014) suggestion that his abstract formulation be tied to empirical observations. Migration systems are defined by elements, dynamics and their interconnections. The interrelated elements of the system are (a) flows of people, ideas, goods and policies, (b) institutions such as inequality and cultures of migration, and (c) migration strategies undertaken via the agency of the migrants. Dynamics are more important than elements in the NTMS and are constituted by feedback mechanisms and the environment. They also govern the emergence of new system elements as well as system reproduction and its disruption (Bakewell 2014, pp. 306, 312). Feedback refers to how migration prompts changes in elements of the system. Levels of feedback mechanisms have been distinguished, with the transmission of information through social networks a "first-order effect" endogenous to the migration system and "second-order effects" (De Haas 2010, p. 1592). The latter are contextual feedback mechanisms at the meso-level that operate in communities and localities, including social stratification, relative deprivation, income distribution and the demand for migrant labor. Because EIs may no longer block emigration, as was found in early Mexican research, we ask how the EI workplace may also be a meso-level context for second-order feedback mechanisms.

Inequality, one of the main elements of the system, can be created, deepened or reduced by wages. Study participants reported the following kinds of income: nominal, real, indirect, relative and the source of income. Nominal wages are the amount of money earned and real wages what it buys. The distinctions between these have been important since 1930s investigations of the cost of living and price indices (Pencavel 2015), although that is not the main focus here. Indirect wages are benefits and bonuses earned above the nominal wage. When distributed by governments, they are called the social wage.

Relative wages are the amount earned in comparison to others, thus being an important form of feedback. If EI employees get less than others, they may experience deprivation which motivates migration. Not only is absolute deprivation (poverty) a migration motivator, but also internal (within country) and international (between countries) relative deprivation (Czaika and De Haas 2011). The latter two can combine producing double relative deprivation. 


\section{Methodology}

Data were collected via in depth interviews. As Carr et al. (2016, p. 4) argue, only people themselves can judge how much income delivers a good quality of living. Qualitative methods were adopted as most suitable for the investigators' goal of observing the complex subjectivity of norms and beliefs forming cultures of migration (Boswell 2008). Moreover, some US and Spanish interviewees were undocumented, making representative samples impossible because there is no list from which to draw a random sample. ${ }^{6}$ Internal migrants, emigrants, returned emigrants and non-migrants were interviewed in both cases because cultures of migration allow broad knowledge of emigration through personal experience, social networks and transborder mass media.

We conducted 57 interviews from 2005 to 2007 with people who had worked in both maquilas in Mexico and in the US. All had emigrated, including maquila employees who made short US trips to work during vacations or reduced work weeks, and those who had left maquila jobs and commuted daily or never returned. Interviewees were asked about migration history, work histories and migratory intentions. We also did six interviews with key informants such as US consulate personnel, support groups for maquiladora workers, and a university administrator of a bilingual program, bringing the total to 63. Five interviews were conducted in Tijuana and the rest in the US, throughout San Diego county and beyond, because the data for the early research had all been collected in Mexico. Table 1 summarizing the sector where employees worked the longest, their age at time of the interview, sex, education and level of maquila job can be found in Additional file 2.

Interviewees were initially recruited at institutions in close contact with migrants: schools, stores, NGOs and social agencies. Then other groups working with migrants were approached and multiple snowball samples were taken, simultaneously and sequentially. The sampling was purposeful, including those whose export jobs varied by income and sector. The size of the sample was determined by the principle of saturation: data collection ended when interviews yielded no new information.

From 2010 to 2013 we conducted 103 in depth interviews using the same and adapted items in Tangiers-Tetouan, Cataluña, Andalucía and Madrid with those having Moroccan export work experience. Spanish areas were selected based on census data indicating regions of greatest Moroccan origin populations. Seventy-nine interviews were done in Morocco and the remainder in Spain. Interviewees included those who had and had not emigrated. Eleven other interviews were conducted with business, government, union and NGO key informants in Morocco, bringing the total to 114. We recruited participants in industrial parks, NGOs and public spaces. Sampling was carried out in the same purposeful way as in CaliBaja. Table 2 showing interviewees' characteristics can be found in Additional file 2.

To update the CaliBaja data, we included 59 interviews with maquiladora employees in Tijuana from 2013 to 2015. This sample contained those who had and had not worked in the US. Interviewees' characteristics are displayed in Table 3 in Additional file 2.

We implemented sociological discourse analysis, which involves simultaneous textual and contextual analysis as well as sociological interpretation, creating a dialogue among

\footnotetext{
${ }^{6}$ The Spanish census includes occupational background of immigrants in country of origin, but makes no distinction between export and domestic industries.
} 
the three levels (Ruiz Ruiz 2009). As each interview was transcribed, the content was reviewed to formulate conceptual categories or variables. This involved labelling what was expressed in light of the context of the data collection situation and its sociological interpretation. These conceptualizations influenced who the next interviewees might be, to find the different properties or values of a category and also new categories. The categories or variables were classified into the most talked about themes (Ryan and Bernard 2003). As with much qualitative research, we did not pre-formulate hypotheses, but sought to remain open to their emergence during the process of category discovery and analysis (Meinefeld 2004, p. 155).

\section{Findings}

Interviewees explained emigration most often in terms of the general theme of their and their households' "getting ahead". For all, this meant the rewards earned for work, specifically, remuneration. A subtheme of work rewards was job quality, e.g. whether work was interesting, repetitive, etc.

\section{Insufficient nominal and decreasing real wages}

I and many of my co-workers emigrated because of the wages. (...) I was working in one maquiladora when there was a change and the (...) owner wanted to pay us workers a little more and the government there wouldn't let them. The money was barely enough for necessities. I would cash my check and then go pay all the stores that had given me credit (...). Next week I would owe them again. (Beatrice ${ }^{7}$ )

When (the call center) opened, the news was that they decided to pay $€ 500$. Really quite a lot, a good wage in Morocco. But now, no (...) The government pressured that company to not pay more (...) I came to Europe because they gave me a 9 month contract, and papers for a visa. (Youssef)

The 2013-2015 Mexican interviewees were paid on average the equivalent of US $\$ 62 /$ week using concurrent exchange rates. Without overtime, this is US $\$ 1.29 / \mathrm{h}$. Workers may not earn this long term due to temporary contracts. Twenty per cent of all maquila jobs were held on contracts of 3 to 6 months (Sánchez 2012).

Beatrice's words indicate that she subsisted on maquila wages but did not break even or have a surplus. We interpret this phenomenon of everyday needs being serviced by debt as life in a poverty trap, or negative income mobility (Carr et al. 2016, p. 5). When trapped in poverty, people move downward into insufficiency; with living wages, they move forward. Beatrice's escape from the trap was emigration. She said unprompted that Mexicans talk about crossing the border in order to escape poverty. In the US, she worked fewer hours for more money in less stressful jobs and was able to exercise daily, whereas her maquila pay didn't cover the basics and heavy workloads made her too tired to exercise. She was more satisfied with her economic situation in the US, even though she found maquila work more interesting and skilled than her US jobs, which were all in cleaning.

${ }^{7}$ All names are pseudonyms. 
Real wages dropped because of exchange rate fluctuations. Baja California is the most dollarized Mexican state, with maquiladoras greatly responsible because suppliers invoice in dollars and real estate prices, which are related to industrial land use, are in dollars (Gerber 2000). Historically, Tijuana's economy functioned in dollars, but in 1976, maquilas began to pay in pesos, which bought less. While foreign companies could buy more for less, employees' costs rose since necessities were priced in dollars (Iglesias 1985, pp. 31-33, 139-40). Emigration is a consequence of devaluation. Because maquilas increase dollarization and take advantage of exchange rates by paying in pesos, the currency market is an internal dynamic of the system.

The minimum wage in Tangiers in 2010 was 10 dihrams (dh) 70 centimos/hour (US\$ 1.20). When asked at her interview's end if she wanted to add anything, a Tangiers woman making wiring harnesses said "First, the salary is not enough, and especially for young men who want to get married (...). It is one reason that makes people think about emigrating".

Currency markets and devaluation were not important dynamics in Morocco where the dirham is in a fixed exchange-rate regime. However, many elements of inequality within Tangiers-Tetouan are part of the wage-labour relation. Inequality is deepened by age discrimination caused by internships. A garment worker reported that her factory employed $700,36 \%$ of whom were interns receiving only $5 \mathrm{dh} / \mathrm{hr}$. Informality is another element of the Tangiers-Tetouan system that contributes to emigration. A sizeable portion of garment workers have no contracts. A leader of the Union of Moroccan Workers reported that in garments, $71 \%$ had contracts, 25\% did not, and $4 \%$ knew nothing about contracts.

Many tangerinos reported that they were not paid for all regular working hours. Overtime work was mandatory but often went unpaid. Several said metaphorically that overtime pay was "swallowed up"; it was promised the following month, but not paid. As one Spaniard with experience in Moroccan garments said "they don't respect the schedule (of hours)". But interviewees said that low or unpaid wages may be compensated for by migrating using vehicles transporting exports, for example, hiding in trucks or boats. Such vehicles serve as material linkages across transnational space.

Within each case, average pay varies by sector in similar ways: agriculture (excluding marijuana), seafood, traditional crafts, garments, shoes, wiring harnesses, call centers. Workers' real wages lead to absolute deprivation, or poverty. Important cross-case differences in labor markets, elements of these migration systems, explain why EI jobs inadequately anchor settlement. Tijuana maquiladoras experience peak seasons with periods of labor shortages. Moreover, interior migrant flows have decreased occasionally because industrial centers have arisen in southern areas such as Bahío, sometimes paying higher wages. During booms, companies compete for workers, spiking rotation. Moroccan EI job creation is insufficient. Between 1985 and 1995, in the urban Tangiers-Tetouan region, the percentage of the economically active population decreased. ${ }^{8}$ From 1999 to 2011, female unemployment there doubled from $7.7 \%$ to 15.7\%. ${ }^{9}$ Tijuana rotation and Tangiers-Tetouan unemployment are evidence of low

\footnotetext{
${ }^{8}$ La Direction Réginale du Haut Commissariat au plan. 2012. Tanger Annuaire Statistique Regionale. Table 16. P. 232.

${ }^{9}$ La Direction Réginale du Haut Commissariat au plan. 2012. Tanger Annuaire Statistique Regional. Table 15, p. 232.
} 
structural integration. Frequent job changes and not having a job reflect unstable occupational structures.

\section{Indirect wages}

EIs may give employees bonuses and governments benefits. Bonuses promote attendance, promptness, and productivity of Mexican workers. Approximately 30\% of maquila workers' pay is in bonuses and benefits (Kopinak et al. 2018), including subsidized meals, transportation, grocery and furniture coupons, etc. Indirect pay in Tijuana enhances people's capacity, for example, by supporting health with food and medical services. They bring poverty level wages closer to a living wage. When orders rise, companies offer better bonuses; during recessions, bonuses decrease or disappear since they are not contractual. The unreliability of bonuses weakens the wage-labour relation. Employers use them to attract employees from other companies, increasing movement between plants and across borders.

Bonuses were far less prevalent in Morocco. An interviewee from the Tangiers Spanish Chamber of Commerce reported that although rotation was problematic, employers could not lower it with bonuses because the majority of workers are women and would give the incentive to male kin. Because of constant surplus labor, EIs do not compete for or control workers with bonuses. Benefits varied by sector, size of company and job, being worse in garments and better in bigger companies. A mechanic reported receiving social security, a contract, health coverage, mutual savings, gifts at Eid-al-Fitr, 4 weeks paid vacation, and the annual circumcision of sons. In contrast, a garment worker said "they don't give us anything". Many garment workers said they received no holiday or sick pay or assistance with medical costs. Most Moroccans reported that their companies deducted social security dues from their pay, but did not register them fully, resulting in incomplete coverage.

Formally employed Mexicans are entitled to health care, housing loans and other credit. Many workers keep maquila jobs as a "back up" and commute to work in the US when possible. Indirect wages may make maquila jobs worth continuing, since workers' US jobs usually have no benefits. In fact, one participant working in a US cafeteria with 8 years of maquila experience said that many people didn't work in exports for the wages because they were so low, but for the bonuses. Fewer bonuses in Morocco indicate less integration into EI labor markets, and more motivation for permanent emigration. Spanish interviewees spoke of state benefits such as medical coverage and unemployment insurance as "rights", explaining EI workers' emigration by their absence.

One important benefit is a letter proving employment, a necessity for acquiring or renewing a visa, another element of the migration system. Visas incorporate migrants into the destination country legally. All employers can provide statements, but since EIs employ such a large portion of the labor force, they give more letters. In Mexico, help getting employees and their families' visas was sometimes part of a package of bonuses used by the employer to lower rotation. It enhances capacity by allowing maquila employees to enter the US where goods are often cheaper. Carlet, who had worked in garments said that unlike most maquilas, hers did not discriminate in terms of age or appearance. Many women over 35 and not fitting beauty norms got jobs there 
intentionally to get support for documents, because they could not get hired in other maquilas.

Getting support for documents is more difficult in Tangiers-Tetouan. Several interviewees reported that EI pay was often insufficient to qualify for a visa. If sufficient, they often could not afford the visa. This is noteworthy, because visas are more expensive in Mexico than Morocco. ${ }^{10}$ Some EIs refused to give workers proof of employment so they could disown them if they complained to authorities about labour practices. A great deal of garment production takes place informally in garages where there is unlikely to be support for visas. Both countries' legislation permits written and verbal contracts, but verbal contracts are more prevalent in Morocco. The method of payment may also be problematic, since many are paid in cash with no pay stubs. Consulates giving visas require 3 months of pay stubs. There is no document such as the laser visa for Moroccan borderlanders, resulting in their entrance most often using tourist visas. The laser visa provides EI workers more possibility to integrate into California than the tourist visa does for Spain because it is issued for a longer period of time.

Even if Moroccans had similar support as Mexicans in getting documents, the differing dynamics in their migration systems may make emigration more difficult. The Strait of Gibraltar, an environmental dynamic, is more difficult to cross. One cannot walk or drive across for free as in CaliBaja, but must pay for the ferry, which costs $€ 27$ or more one way, the equivalent of $297 \mathrm{dh}$ or $28 \mathrm{~h}$ of work at the wage reported above. The phenomenon of CaliBaja employees supplementing EI wages by commuting, and subsequently emigrating, is unaffordable in Tangiers-Tetouan except for managers.

Intra-societal security and the securitization of borders are two migration system dynamics which may contribute to EI employees using the visas EIs assist them with to cross the border. Both cases have narco-economies with northern neighbours pressuring to reduce them. Mexico arrested organized crime leaders, contributing to increased violence among their underlings competing for business (Shirk and Wallman 2015). Many maquila employees emigrated to escape conflict. King Hassan II declared a war on drugs (McMurray 2001), a condition Morocco met in return for negotiating a trade treaty with the EU (Andreas 2000, p. 32). Europe and Morocco are unwilling to end the drug trade because it contributes to economic stability and limits illicit emigration (p. 134). The king has not arrested narco leaders, thereby avoiding Tijuana's pervasive violence. In order to contain the drug trade and prevent terrorism, both borders have been securitized. At the CaliBaja border, more time and stress are expended in crossing, motivating commuters' emigration. White (2007, p. 798) shows how the Spanish securitization of migration "has not resulted in the cessation of immigration by Moroccans or others to Spain".

Some kinds of income can be found more easily abroad than in EIs, drawing people across the border. Both countries require employers to pay compensation for unprovoked dismissal, but companies often default and governments fail to enforce the law. Foreign labor markets requiring less work for more pay and having less age discrimination, substitute for unemployment insurance. Pensions are very low or non-existent after EI jobs; employees emigrated to finance their and their parents' retirement. Loans are also more readily available abroad. Even if one has the same amount of money at

\footnotetext{
${ }^{10}$ One Moroccan interviewee said a visa cost $€ 60$, which at the time of the interview was $660 \mathrm{dh}$ or $62 \mathrm{~h}$ of work at the Tangiers minimum wage. A non-immigrant visa for Mexicans is US $\$ 160$, or $124 \mathrm{~h}$ of work at the wages reported above.
} 
home or abroad, the enforcement of labor law in the destination country makes income there more secure. Lesser income security in origin countries is an element of the migration system.

\section{Relative wages}

While the findings reported above emphasize the more econometric aspects of wages (e.g. money earned, bonuses), this subsection highlights social psychological aspects. These are indicative of what Carr et al. $(2016$, pp. 7,18$)$ call subjective well-being and help us understand "how the agency of social actors shapes the system" (Bakewell 2014, p. 306). Migration economists in early research pointed to the objective character of immigrants' economic integration, e.g. wage parity of immigrants and natives with identical characteristics (Amit and Riss 2014). Here, we demonstrate a subjective side of income.

Horowitz (2009) found that newcomers to Reynosa maintained origin locations as references in his study of workers' resistance to poor maquila wages and working conditions. Our interviewees also said that with northern opportunities to improve, they felt fewer scarcities than in hometowns. Many had remitted when arriving at the border, but after approximately 15 years stopped, needing to support growing local families. When asked when they first started to think about emigrating, many said only after moving north for EI jobs. They adopt US standards as references, and experience a second form of relative deprivation: international. This is part of the agency undertaken by internal migrants having become borderlanders, i. e. identifying with material comfort abroad. Horowitz (2009, p. 683) asks, "Why endure the risks of collective struggle when the individual strategy of crossing holds out such great material possibility?"

In a critique of four decades of Acculturation Psychology which stresses culture, a group of psychologists have created a Liberation Psychology perspective on immigrant integration (Albar et al. 2010). Migrants are viewed as vulnerable and at risk of oppression, who develop a critical vision in their community groups and overcome exploitation in order to integrate. Our findings, like that of Howowitz's, are that internal migrants do develop a critical vision of wages, but exit by emigrating rather than organizing for better pay. Our findings differs from those of Albar et al. (2010) partly because our cases are internal migrants in border cities, who may cross borders relatively easily, maintaining former ties as transationals while perhaps acculturating as emigrants. Thus, while wages are an important element of the migration system leading to inequality, borders are important system dynamics making it easier to leave and facilitating return visits because they are internal to the migration systems.

Many interviewees reported wanting to emigrate when they saw the money and goods with which emigrants returned. A noteworthy aspect of cultures of migration in both cases is that those south of the border can watch their northern neighbour's television, observing consumer levels. The significance of international relative deprivation is demonstrated by the counterfactual. Those who opposed emigration tended to express skepticism, saying returnees fabricated stories of success and had rented the fancy cars in which they visited. This was especially true of export workers who had some NGO affiliation, who preferred to stay to improve their communities. They maintained 
their homelands as references, but worked abroad when they "had to" because of special needs or unemployment. Those involved in NGOs were more often return emigrants who support the Liberation Psychology perspective on integration.

The degree to which the receiving society is welcoming also affects migrant integration (Huddleston et al. 2013). Some native residents in our cases expressed negative attitudes toward internal migrants. Tangerinos often disapproved of southerners because they accepted lower pay. A Mexican emigrant said he had disliked living in Tijuana because it was not really Mexico due to its composition by people from many different parts of the country.

EIs increase inequality by introducing previously non-existent wage inequality. They provide a social context at the meso-level in which at least three income comparisons are made: a) between people doing the same work in different nations, b) former EI employees who emigrated and those remaining, and c) native EI employees and foreign personnel doing the same work. These comparisons are an important form of secondorder feedback in the migration system which can create international relative deprivation stimulating emigration.

Luisa had worked in the only maquila near her hometown in Jalisco for 5 years. When the factory closed she and her family moved to California. She said "they know that they are doing the same work as someone in the United States and they know that they are earning much less."

Hafizah, a Tangiers garment worker, had a cousin working in another EI who bought a tourist visa from a coworker. She said of her cousin who returned annually for vacation, "She went seven years ago and has already bought her house ( ...) in Morocco. And us, ( ...) we are paying rent. (...) If I had gone I would be better off. (...) If I found something better abroad, I would go".

In Tijuana, US professionals are paid more than equally qualified natives doing the same work. When Mario acquired a green card with family assistance, he asked for a raise to the US level, and was fired. He became a manager in the US and emigrated. In Tangiers-Tetouan, Inaya, who had made wiring harnesses for 10 years, said, "foreigners came. They worked at the same jobs just like we did. They got $20 \mathrm{dh} / \mathrm{hr}$., and we got, ( ...) $8 \mathrm{dh}$ ( ...) Besides that, they weren't working under pressure like we were". Her friend had gone to Spain to work in strawberries for 6 months, earning what Inaya did in 2 years. She regretted staying.

Azzam, with EI experience, went to Seville, was caught and returned. He expressed how EI employment contributed to his adoption of European culture and his sense that he belonged there.

For me, the export factories (...) spur migration, because the foreigners come who are in charge and they have a different treatment. (...) We see them and say that they live a better life than ours. (...) They pass on their culture and their civilization and how they live in an indirect way (...) that makes us dream of one day becoming like them (...). I prefer to work as a bus driver in Europe than a director of an (...) export company.

Such cultural comparisons are less important in CaliBaja because of a greater shared regional culture. 


\section{Discussion}

Former President Salinas's call for Mexico to export goods, not people has been partly fulfilled by maquiladora production. This work shows how EI wage characteristics can foster the export of people as well. This results from the wage-labour relationship. This work extends our knowledge about EI wages and migration by providing two more sets of results to those already reported for Asia (Stalker 2000). A scale of EI sites is proposed for future research. Tijuana maquilas have a much more institutionalized wagerelation and are closer to Korea and Taiwan, whereas the Tangiers-Tetouan relation is more incomplete and similar to Thailand. Contributing to its incompleteness is the informality of its EI labor market, garage workplaces, payment in cash without pay stubs, and fluctuations in the length of the working day. An important factor in the underdeveloped wage-labor relationship in Tangiers-Tetouan is deficient indirect pay. Fewer bonuses there indicate less integration in labour markets and EI support for visas in Tijuana is a sign of legal inclusion in the US. Once in the US, many tijuanenses integrate economically by working illegally. These findings on indirect pay help fill the gap in the under-studied area of how social policies such as benefits for migrants influence social inclusion outcomes (Huddleston et al. 2013, p. 24).

By conceptualizing the living wage economically and also by the capacity of people to do what they value (e.g. purchase housing, marry), this work allows us to understand the more subjective processes such as relative deprivation which result from comparisons between natives, emigrants and foreigners. Natives feel unable to meaningfully participate in their homelands, motivating emigration.

EIs restructure remuneration, creating wage tiers. Two exist in Mexico, foreign personnel and Mexicans, three in Morocco with the addition of internships. EI employees' agency is illustrated by showing how the relative dimension of wages creates feedback mechanisms within social networks and the workplace, transforming borderlanders and internal migrants into emigrants. Thus, using the concept of the living wage, as elaborated by the psychologist Carr and his managerial academic co-authors, we demonstrate how social scientists can detect the more social psychological aspects of wages as well as their ability to provide economic sustenance.

Except for the NGO affiliates interviewed, our findings differ from those of Liberation Psychology which argues that as a result of developing their own vision, immigrants in community organizations oppose exploitation and overcome marginalization, thereby integrating. Our interviewees did develop their own critique but more often emigrated rather than integrating south of their borders. We interpret the difference in the findings as part of our study of migrant integration in the context of the NTMS, which highlights the role of borders as system dynamics. The thinness or thickness of borders determines whether emigrants or transnationals are more likely to result from the migration process.

The elements of the two migration systems elaborated in the findings, plus others, are summarized in Table 4 which can be found in Additional file 3 . The application of the NTMS in this work is heuristically valuable because it directs researchers' focus not only to origin and destination locations but also transnational areas, such as CaliBaja where a national border weaves through an international metropolis. This addresses Hadj Abdou's (2019, p. 2) direction to "look beyond the nation state to truly unsettle common sense ideas about integration". 
Multinationals relocate to these borders in part because they are adjacent to large markets and have abundant low cost labour. Their employees are integrated into transnational production, which is part of a system with preexisting migration patterns. EIs integrate internal migrants and borderlanders into regional and global systems which are part of international economies, making emigration more likely.

The findings of regional migrant integration leads us to reject Favell's (2019) suggestion that the concept of integration only be used on a global level. After our data collection, tens of thousands of asylum seekers who were interior Mexicans, Haitians from Brasil and Central Americans arrived in Tijuana. Given the very slow process of deciding asylum claims and new policies forcing them to stay in Mexico awaiting the outcome, many have become integrated with documents and via maquila employment. Should their claims fail, they may be integrated into Mexico nationally, albeit perhaps temporarily.

Despite the fact that deportations of Mexican immigrants has increased during the current and previous US administrations, the findings reported here are highly relevant in the CaliBaja system. In fact, deportations from the border region have decreased, while those removed from the interior have increased (ICE 2017). Spanish immigration policies have been more tolerant than US ones, where a work contract secures entry and a greater proportion of the undocumented have been recently regularized.

\section{Conclusion}

This analysis of how EI wages incorporate internal migrants and borderlanders socioeconomically finds integration to be weak. Concerning the social aspects of socioeconomic integration, natives compare themselves with foreigners doing the same work and with returning expatriates, creating international relative deprivation. Such comparisons are also facilitated by cultures of migration, in which people have knowledge of emigration and how to do it. Economically, poverty level wages and job insecurity generate emigration. The Tijuana labour market gives rise to rotation and the Tangiers-Tetouan one unemployment, both evidence of low structural integration. Indirect pay in Mexico improves income, but is not enough to prevent international relative deprivation which leads to emigration. Its presence in Tijuana and absence in the US tethers EI employees to maquila jobs, making emigration a multi-step process, with several trips. The lack of benefits in Morocco and generous social wages in Spain promote one step emigration. In terms of legal integration, the laser visa in CalifBaja permits entry into the US where migrants may integrate economically by working illegally. The use of only the tourist visa in Tangiers-Tetouan gives migrants less footing in Spain.

A limitation of this research is that findings cannot be generalized beyond the two cases studied and may differ in other locations. However, studying the two regions chosen does contribute to our knowledge of migrant integration because most previous work in the area has been on high-income countries. The inclusion of Tijuana and Tangiers-Tetouan as low wage producers in international economies decreases the integration south of the borders of internal migrants and boderlanders who make the products. Those outside the international economy, from Mexican and Moroccan interiors where work is scarce and wages even lower are also displaced when drawn northward. Although it is beyond the scope of this paper, it can be demonstrated that export 
processing has de facto divided Mexico and Morocco increasing regional inequalities. Another limitation of the paper is the lack of analysis of non-wage migration motivators. Interviewees infrequently mentioned other reasons such as escaping corruption and religious norms, taking advantage of recreational and educational amenities abroad and family unification.

It is not wages alone as institutionalized elements of migration systems which impact emigration. Comparing the two cases with different dynamics highlights the interaction of border characteristics, dynamics of the system, with EI employment. The relative ease of crossing the CaliBaja border makes emigration a more likely reaction to poor wages than in Morocco, where the Strait of Gibraltar presents a greater obstacle.

The comparison of wage-labor relationships and the finding that they are more underdeveloped in Tangiers-Tetouan might lead us to hypothesize that TangiersTetouan EIs, like those in Thailand, would send a higher proportion of their labor force abroad. However, interpreting the findings via the NTMS permits the separation of the impact on migration of wage induced inequality from the dynamics of the environment and feedback to show how the latter interact with EI wages.

The NTMS also highlights the effect of other dynamics on emigration such as currency markets, insecurity due to crime, securitization of the border and second order feedback mechanisms within the EI workplace. Dynamics enhance the impact of all dimensions of EI wages on emigration in CaliBaja, contributing to it. This finding supports the NTMS's proposition that dynamics are more important than elements in migration systems. Due to their impact, we suggest that future research test the hypothesis that a larger proportion of those with EI experience emigrate in CaliBaja. Since support for documents is weaker in Tangiers-Tetouan, a larger portion of emigrants from there are predicted to be undocumented. Future work should also assess the effect of Tangiers' first large auto assembler on wages and migration. It was inaugurated in 2012, at the mid-point of our data collection period. Auto assembly usually pays more than other EI sectors.

\section{Supplementary information}

Supplementary information accompanies this paper at https://doi.org/10.1186/s40878-020-00198-x.

Additional file 1: Figure 1. Map of Tijuana and San Diego. Figure 2. Strait of Gibraltar With Shipping Traffic.

Additional file 2: Table 1. Characteristics of CaliBaja Interviewees (2005-2007). Table 2. Characteristics of Moroccan Interviewees (2012 - 2013). Table 3. Characteristics of Tijuana Interviewees (2013-2015).

Additional file 3: Table 4. Elements of Migration Systems in CaliBaja and Northern Morocco-Spain.

Acknowledgements

The Centers for Comparative Immigration Studies and US-Mexican Studies at UC, San Diego provided institutional support.

\section{Authors' contributions}

All authors contributed to the research design, collected and coded data. KK analysed the data and wrote the article. $J H$, RMSM and ATR read and commented on the article with suggestions and corrections. All authors read and approved the final manuscript.

Funding

Funding for planning the research was obtained from the Social Science and Humanities Research Council of Canada (861-2006-2014). Data collection was supported by the Social Science and Humanities Research Council of Canada (861-20098), the Sociedad Mexicana Pro Derechos de la Mujer A.C. and the Plan Nacional de Investigación Cientifica del Ministerio de Ciencia e Innovación (CSO2010-16112). 
Availability of data and materials

Not applicable.

\section{Competing interests}

The authors declare that they have no competing interests.

\section{Author details}

${ }^{1}$ King's University College at Western University, 152 Albert St. \#24, London, ON N6A 1M1, Canada. 'Wilfrid Laurier University, 75 University Avenue, Waterloo, ON N2L 3C5, Canada. ${ }^{3}$ Universidad de Granada, Calle Alhamar, 23, 5, B, 18005 Granada, Spain.

Received: 20 September 2019 Accepted: 7 July 2020

Published online: 28 September 2020

\section{References}

Acosta, F., Reyes, A., \& Solís, M. (2015). Crisis económica, migración interna y cambios en la estructura ocupacional de Tijuana México [Economic crisis, internal migration and changes in the occupational structure of Tijuana, Mexico]. Papeles de Poblacion, 21(85), 9-46.

Albar, M. J., Camacho, C., García-Ramírez, M., El Jebari, T., El Karkri, M., Hernández-Plaza, S., et al. (2010). Contributions of liberation psychology to the integration of the immigrant population. Psychosocial Intervention, 19(3), 223-234. https:// doi.org/10.5093/in2010v19n3a3.

Amit, K., \& Riss, L. (2014). The subjective well-being of immigrants: Pre-and post-migration. Social Indicators Research, 119(1), 247-264.

Anderson, J. (2012). Dynamics of economic development gaps: Comparing the U.S.-Mexico and Spain-Morocco borders. In J. Román, \& D. Shirk (Eds.), Borders Fronteras (pp. 119-129). San Diego: Transborder Institute and Madrid: Ciudadanía Y Valores Fundación.

Andreas, P. (2000). Border games: Policing the U.S.- Mexico divide. Ithaca: Cornell University Press.

Bakewell, O. (2014). Relaunching migration systems. Migration Studies, 21(3), 300-318. https://doi.org/10.1093/migration/ mnt023.

Bensusán, G., Carrillo, J., \& Micheli, J. (2017). ¿Está realmente la innovación asociada a la mejora social? ¿Qué podemos aprender de los estudios de caso? [Is innovation really associated with social improvement? What can we learn from case studies?]. In J. Carrillo, G. Bensusán, \& J. Micheli (Eds.), ¿Es posible innovar y mejorar laboralmente? [Is it possible to innovate and improve the workplace?] (pp. 627-690). Azcapotzalco: Universidad Autonónomo Metropolitana.

Bensusán, G., \& Reygadas, L. (2000). Relaciones laborales en Chihuahua: Un caso de abatimiento artificial de los salarios [Labo relations in Chihuahua: A case of the artificial depression of wages]. Revista Mexicana de Sociología, 62(2), 29-57. https:// doi.org/10.2307/3541358.

Boswell, C. (2008). Combining economics and sociology in migration theory. Journal of Ethnic and Migration Studies, 34(4), 549-566. https://doi.org/10.1080/13691830801961589.

Breidahl, K. (2017). Scandanavian exceptionalism? Civic integration and labour market activation for newly arrived immigrants. Comparative Migration Studies, 5(2). https://doi.org/10.1186/s40878-016-0045-8.

Bustamante, J. (1983). Maquiladoras: A new face of international capitalism in Mexico's northern frontier. In J. Nash, \& M. Fernández-Kelly (Eds.), Women, men, and the international division of labor (pp. 224-256). Albany: SUNY Press.

Carr, S., Parker, J., Arrowsmith, J., \& Watters, P. (2016). The living wage: Theoretical integration and an applied research agenda. International Labour Review, 155(1), 1-24. https://doi.org/10.1111/j.1564-913X.2015.00029.X.

Carrillo, M. (1990). Maquiladoras y migración en México [Maquiladoras and Migration in Mexico]. Puebla: Asesoría y Consultoría Económica.

Charoenloet, V. (2001). Economic Crisis, Social Development and Challenges for the Trade Unions: Thailand. In L. Cuyvers (Ed. ), Globalisation and Social Development: European and Southeast Asian Evidence (pp. 171-191). Cheltenham: Elgar.

Chávez, S. (2007). The making of a border labor migration system: Government policies, labor markets and social networks in Tijuana. Unpublished doctoral dissertation. Ithaca: Cornell University.

Czaika, M., \& De Haas, H. (2011). The role of internal and international relative deprivation in global migration (IMI Working Papers Series 2011, no. 35). International Migration Institute and University of Oxford.

De Haas, H. (2008). North African migration systems: Evolution, transformations, and development linkages. In S. Castles, \& R Delgado Wise (Eds.), Migration and development: Perspectives from the south (pp. 143-174). Geneva: IOM.

De Haas, H. (2010). The internal dynamics of migration processes: A theoretical inquiry. Journal of Ethnic and Migration Studies, 36(10), 1587-1617. https://doi.org/10.1080/1369183X.2010.489361.

De Haas, H., \& Vezzoli, S. (2014). Migration and development on the south-north frontier: A comparison of the Mexico-US and Morocco-EU cases. Journal of Ethnic and Migration Studies, 39(7), 1041-1065. https://doi.org/10.1080/1369183X.2013. 778019

Delgado Wise, R., \& Márquez Covarrubias, H. (2008). The Mexico-United States migratory system: Dilemmas of regional integration, development and emigration. In S. Castles, \& R. Delgado Wise (Eds.), Migration and development: Perspectives from the south (pp. 113-142). Geneva: IOM.

Dussel Peters, E. (2004). Who reaps the productivity growth in Mexico? Convergence or polarization in manufacturing real wages, 1988-1999. In G. Otero (Ed.), Mexico in transition: Neoliberal globalism, the state and civil society (pp. 121-137). London: Zed Books.

Fafchamps, M. (2009). Human capital, exports, and earnings. Economic Development and Cultural Change, 58(1), 111-131. https://doi.org/10.1086/604721.

Favell, A. (2019). Integration: Twelve propositions after Schinkel. Comparative Migration Studies, 7(21). https://doi.org/10.1186/ s40878-019-0125-7.

Fernández-Kelly, M. (1983). For we are sold, I and my people. Albany: SUNY Press. 
Fussell, E. (2000). Making labor flexible: The recomposition of Tijuana's maquiladora female labor force. Feminist Economics, 6(3), 59-79. https://doi.org/10.1080/135457000750020137.

Fussell, E. (2004). Sources of Mexico's migration stream: Rural, urban, and border migrants to the United States. Social Forces, 82(3), 937-967. http://www.jstor.org/stable/3598362.

Gerber, J. (2000). Dollarization in Baja California and the rest of Mexico. San Diego Dialogue Report, 3(12), 5.

Hadj Abdou, L. (2019). Immigrant integration: The governance of ethno-cultural differences. Comparative Migration Studies, 7(21). https://doi.org/10.1186/s40878-019-0124-8.

Horowitz, M. (2009). Maquiladora production, rising expectations, and alterglobalization strategy. Critical Sociology, 35(5), 677688.

Hualde, A. (2007). Quién aprende en las maquiladoras? [Who learns in maquiladoras?]. In J. Carrillo, \& R. Barajas (Eds.), Maquiladoras fronterizas [Border maquiladoras] (pp. 225-262). México: COLEF.

Huddleston, T., Niessen, J., \& Tjaden, J. D. (2013). Using EU indicators of immigrant integration. In Final Report for DirectorateGeneral for Home Affairs. Brussels: European Commission.

ICE (Immigration and Customs Enforcement). (2017). Fiscal year 2017 enforcement and removal operations report. http://www ice/gov/removal-statistics/2017

Iglesias, N. (1985). La flor mas bella de la maquiladora [The most beautiful flower of the maquiladora]. Tijuana: SEP/Cefnomex.

Kinoshita, Y. (2008). Is foreign direct investment a panacea? IMF Research Bulletin, 9(1), 1-3. https://doi.org/10.5089/ 9781451959376.026

Kopinak, K., Quintero Ramírez, C., \& Hennebry, J. (2018). Working conditions in border export industries. In A. Trinidad Requena, R. Soriano-Miras, M. Solís, \& K. Kopinak (Eds.), Localized global economies on the northern borderlands of Mexico and Morocco (pp. 115-152). New York: Palgrave.

Lane, J., Hakim, G., \& Miranda, H. (1999). Labor market analysis and public policy: The case of Morocco. The World Bank Economic Review, 13(3), 561-578. https://doi.org/10.1093/wber/13.3.561.

McMurray, D. (2001). In and out of Morocco: Smuggling and migration in a frontier boomtown. Minneapolis: University of Minnesota Press.

Meinefeld, W. (2004). Hypotheses and prior knowledge in qualitative research. In U. Flick, E. von Kardorff, \& I. Steinke (Eds.), A companion to qualitative research (pp. 153-158). London: Sage.

Muller, C., \& Nordman, C. (2008). Task organization, human capital and wages in Moroccan exporting firms (CREDIT research paper no. 08/12). University of Nottingham.

Nekby, L. (2002). How long does it take to integrate? Employment convergence of immigrants and natives in Sweden (Working Paper Series 185). Trade Union Institute for Economic Research.

Pencavel, J. (2015). Keynesian controversies on wages. The Economic Journal, 125, 295-349. https://doi.org/10.1111/edoj. 12201/ecoj.12201.

Rios-Vargas, A. (2015). Marruecos y México: Dos modelos de securitización migratoria en las fronteras de la globalización [Morocco and Mexico: Two models of migratory securitization on the borders of globalisation]. CienciaUAT, 10(1), 47-55. https://doi.org/10.1177/1525822X02239569.

Rubery, J. (1997). Wages and the labour market. British Journal of Industrial Relations, 35(3), 337-366. https://doi.org/10.1111/ 1467-8543.00058.

Ruiz Ruiz, J. (2009). Sociological discourse analysis: Methods and logic. Forum: Qualitative Social Research, 10(2), 26-71 paragraphs. http://nbn-resolving.de/urn:nbn:de:0114-fqs0902263.

Ryan, G., \& Bernard, R. (2003). Techniques to identify themes. Field Methods, 15(1), 85-109. https://doi.org/10.1177/ $1525822 \times 02239569$.

Saharso, S. (2019). Who needs integration? Debating a central, yet increasingly contested concept in migration studies. Comparative Migration Studies, 7(16). https://doi.org/10.1186/s40878-019-0123-9.

Sánchez, K. (2012). Trabajan bajo contrato temporal 20\% de empleados en maquila [20\% of employees in the maquila work under temporary contracts]. Frontera [Border] April 8.

Seligson, M., \& Williams, E. (1981). Maquiladoras and migration: Workers in the Mexico-United States border industrialization program. Austin: Mexico-US Border Research Program.

Shirk, D., \& Wallman, J. (2015). Understanding Mexico's drug violence. Journal of Conflict Resolution, 59(8), 1348-1376. https:// doi.org/10.1177/0022002715587049.

Soriano-Miras, R. (2018). Inmigración e identidad social: Silimilitudes y diferencias en el proyecto migratorio de mexicanas a EE.UU.y mujeres marroquíes a España [Immigration and social identity: similarities and differences in the migratory project of Mexican women in the US and Moroccan women in Spain]. Migraciones, 23, 117-150. https://revistas.comillas. edu/index.php/revistamigraciones/article/view/1450.

Stalker, P. (2000). Workers without frontiers. Boulder: Lynn Rienner.

Trinidad Requena, A., Soriano Miras, R., \& Barros Rodríguez, F. (2018). Working conditions in the export industry of northern Morocco: Legal framework and situation on the ground. International Labour Review, 157(2), 307-329.

Wanner, P. (2019). Integration of recently arrived migrants in the Swiss labour market - Do the reasons for migration matter? In I. Steiner, \& P. Wanner (Eds.), Migrants and expats: The Swiss migration and mobility nexus, IMISCOE Research Series. Cham: Springer.

White, G. (2007). Sovereignty and international labor migration: The "security mentality" in Spanish-Moroccan relations as an assertion of sovereignty. Review of International Political Economy, 14(4), 690-718. https://doi.org/10.1080/ 09692290701475411.

\section{Publisher's Note}

Springer Nature remains neutral with regard to jurisdictional claims in published maps and institutional affiliations. 